\title{
Influence of the cable's layout on the shearing resistance of prestressed concrete beams
}

\section{Influência do traçado do cabo na resistência ao cisalhamento de vigas de concreto protendido}
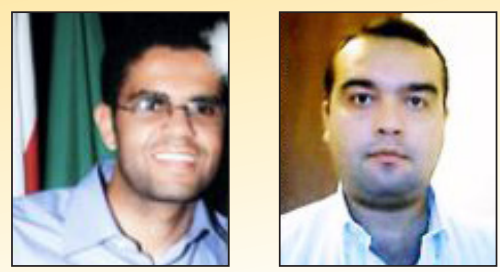

O. A. SOUZA JUNIOR orivaldo.souza@ifap.edu.br

D. R. C. OLIVEIRA b denio@ufpa.br

\begin{abstract}
Little information on experimental investigations regarding the influence of the prestressing forces in the shear resistance of prestressed beams is found in the technical literature. Thus, it was experimentally evaluated the shear resistance of six post-tensioned prestressed concrete beams with cross section of $(150 \times 450) \mathrm{mm} 2$, total length of $2400 \mathrm{~mm}$ and concrete's compressive resistance of $30 \mathrm{MPa}$, with the variables of this work being the layout of the prestressing cable, straight or parabolic, and the stirrups geometric rate. Verticals displacement, steel and concrete's strains and a comparison of the experimental loads with the estimates of ACI 318, EUROCODE 2 and NBR 6118: 2014 codes are presented and discussed. The results showed that the cable's parabolic layout increased the beams' shear resistance in up to $16 \%$ when compared to beams with straight cables.
\end{abstract}

Keywords: prestressed concrete, shearing, beam.

\section{Resumo}

Poucas informações relativas às investigações experimentais sobre a colaboração da protensão na capacidade resistente ao esforço cortante dos elementos estruturais protendidos, são encontradas na literatura técnica. Assim, foi avaliado experimentalmente o desempenho ao cisalhamento de seis vigas de concreto protendido com cordoalhas engraxadas, seção transversal de $(150 \times 450) \mathrm{mm} 2$, comprimento de $2400 \mathrm{~mm}$ e resistência à compressão do concreto de $30 \mathrm{MPa}$, sendo que as variáveis do trabalho foram o traçado do cabo de protensão, reto ou parabólico, e a taxa de armadura transversal. São apresentados os resultados para os deslocamentos verticais, deformação do aço e do concreto e as cargas últimas experimentais comparadas com as estimadas das normas ACI 318, EUROCODE 2 e NBR 6118: 2014. Os resultados mostraram que as vigas com traçado inclinado apresentaram aumento na resistência ao cisalhamento em até $16 \%$ quando comparadas às vigas com cabos retos.

Palavras-chave: concreto protendido, cisalhamento, viga. 


\section{Introduction}

In the design of reinforced concrete structures, tensile by bending generated by loading is resisted only by steel, delaying the cracking of the concrete. The reinforcement called passive reinforcement, intended to receive the tensile forces not absorbed by the concrete, working only when requested. In prestressed concrete structures the force applied on the cables is transmitted to the concrete, resisting the tensile stresses by flexure and assisting the passive reinforcement. The prestressing reinforcement, called active reinforcement is placed in the structural element not only to compress and generate the necessary compressive stress so that the concrete can absorb the tensile stresses generated by loadings, but also to resist to external loadings, providing many advantages, such as reduction of the shear forces by the action of the vertical component generated by the prestressing. In the case of inclined cables, the increase of compressive stresses and reducing tensile stresses, vertical displacements and cracking reduction, with the structure remaining predominantly in the stage I along its useful life.

According Naaman [1], the longitudinal prestressing introduces in the concrete elements with inclined prestressed cables a vertical component that depends on the overall strength of the cable and reduces the shear loading. Figure 1 shows a prestressed concrete beam with a section length $d x$ and the components generated by prestressing. The prestressing also induces compressive stresses which contribute to reduce principal tensile stresses so that shear cracking seems more vertical. According to Leonhardt and Monnig [2] the struts inclination varies from $15^{\circ}$ to $30^{\circ}$. However, in lengths with concentrated loads or on intermediate supports of continuous beams, for example, shear cracks appear and inevitably reach $45^{\circ}$. This paper aims to evaluate the contribution of prestressing in reducing of the shear forces in six beams through the vertical component generated by the inclination of the prestressing cables, being three with parabolic cables and three with straight cables, and for each cable's layout three geometrical rates of stirrups were used, and the experimental results were compared to estimates of $\mathrm{ACl}$ 318 [3], EUROCODE 2 [4] and NBR 6118 [5] codes.

\section{Available information}

Some research tried to understand the parameters that influence the shear strength of prestressed concrete beams. Laskar and Hsu [6] studied the shear behavior of five prestressed concrete beams with $7620 \mathrm{~mm}$ length, average $f_{\mathrm{c}}$ ' of $70.5 \mathrm{MPa}$, cross

Figure 1 - Prestressing components (Naaman (1))
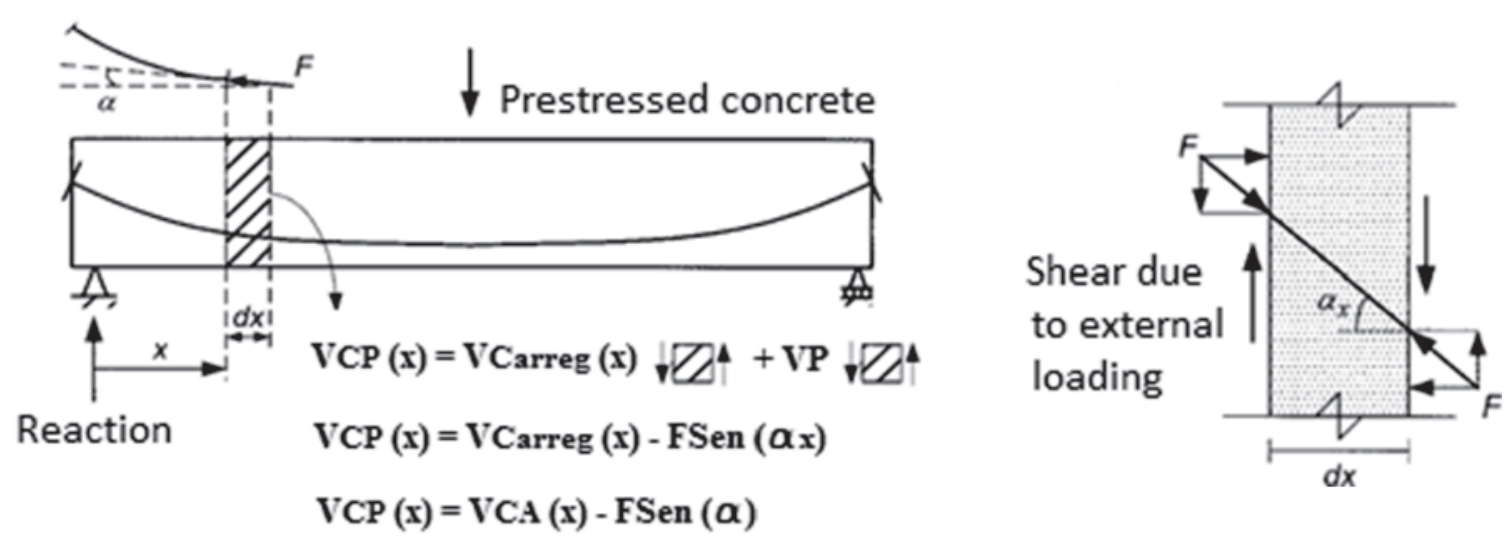

Table 1 - Variables and failure modes of the beams tested by LASKAR and HSU (6)

\begin{tabular}{|c|c|c|c|c|c|c|c|c|c|c|c|c|}
\hline Beam & $\underset{(\mathrm{mm})}{\mathrm{I}}$ & $\begin{array}{c}\text { D } \\
(\mathrm{mm})\end{array}$ & $\begin{array}{c}b_{f} \\
(m m)\end{array}$ & $\begin{array}{c}b_{w} \\
(\mathrm{~mm})\end{array}$ & $\begin{array}{c}f_{c}^{\prime} \\
(M P a)\end{array}$ & $a / d$ & Traç. & $\begin{array}{l}\rho_{w} \\
(\%)\end{array}$ & $\begin{array}{c}\mathrm{s} \\
(\mathrm{mm})\end{array}$ & $\begin{array}{c}V_{u} \\
(k N)\end{array}$ & $\begin{array}{c}\mathrm{M}_{\mathrm{u}} \\
(\mathrm{kN} \cdot \mathrm{m})\end{array}$ & $\begin{array}{l}\text { Failure } \\
\text { mode }\end{array}$ \\
\hline B1 & \multirow{5}{*}{7620} & \multirow{5}{*}{568} & \multirow{5}{*}{150} & \multirow{5}{*}{50} & 72,4 & 1,61 & $R$ & 0,17 & 250 & 840,2 & 892 & \multirow{2}{*}{$\begin{array}{c}\text { Web } \\
\text { shearing }\end{array}$} \\
\hline B2 & & & & & 74,5 & 1,61 & $R$ & 0,95 & 178 & 1040,8 & 1106 & \\
\hline B3 & & & & & 64,6 & 1,61 & P. & 0,95 & 178 & 1014 & 1077 & \multirow{3}{*}{$\begin{array}{l}\text { Flexure- } \\
\text { shearing }\end{array}$} \\
\hline B4 & & & & & 71,0 & 4,29 & $R$ & 0,17 & 250 & 430 & 470 & \\
\hline B5 & & & & & 64,5 & 4,29 & $P$ & 0,17 & 250 & 450 & 490 & \\
\hline
\end{tabular}


section with effective height of $568 \mathrm{~mm}$, with the transversal reinforcement geometrical rate, the layout of the prestressing cable and the relationship between the shear span and the useful height $(\mathrm{a} / \mathrm{d})$ as variables. The beams B1, B2 and B4 presented straight layout and were designed to shear failure mode, with ratio $a / d$ of 1.61 , and B3 and B5 beams with parabolic layout, also with shear failure, showed ratio $a / d$ of 4.29 . The transverse reinforcement ratio of beams ranged from $\rho_{w}=0.17 \%$ for beams B1, B4 and B5 and of $\rho_{w}=0.95 \%$ for beams B2 and B3. Table 1 presents the test parameters, beyond the ultimate experimental loads and failure modes.

It was observed that the cracking stress were higher for beams B1 and B2 with straight cables as compared to the beams with parabolic cables, B3 and B5, because the horizontal component of the cable. The beams with parabolic cables were more efficient in relation to the beams with straight cables against shear forces reducing around $10 \%$ these forces of the beams in relation to beams with straight cables. The experimental results also showed that the beams had two failure modes, according to the North American standard $\mathrm{ACl}$ 318/2011: flexure-shearing and web shearing. The beams that failure with web shear presented brittle fracture, while the beams that failure by flexure-shearing showed ductile behav- ior. The beams with ratio $a / d$ of 4.29 presented ductile failure compared to the beams with $a / d$ of 1.61 , showing the strong influence of this parameter on the shear strength of prestressed beams. The beams B1 and B2, which exhibited as variables just the transversal reinforcement rates, showed brittle failure due to the low ratio $a / d$, with the resistance of the beam B1 being $30 \%$ greater than that of the beam B2.

MacGREGOR [7] evaluated the influence of the prestressing cable's layout on the shear strength of twenty-two prestressed concrete beams with angle of inclination measured from the geometric center of the prestressing reinforcement, in the central section, till the longitudinal axis of the beam, ranging from zero to ten degrees. Table 2 presents the characteristics of the tested beams by MacGREGOR [7]. The behavior of the beams after initial crack (decompression state) was changed according to the inclination of the cables. For beams with higher inclinations of the cables was verified an average resistance gain of $25 \%$, from the formation of the first crack till the failure, when compared to the other beams of lower inclinations. For beams with lower inclinations there was no significant increase in load, from the formation of the first crack up to the failure. This was due to the horizontal component to the cables with lower inclinations be greater than for cables with higher

\section{Table 2 - Characteristics of the MacGREGOR's (7) beams}

\begin{tabular}{|c|c|c|c|c|c|c|c|}
\hline Beam & $\begin{array}{c}f_{c}^{\prime} \\
(M P a)\end{array}$ & $\begin{array}{c}b_{f} \\
(m m)\end{array}$ & $\underset{(\mathrm{mm})}{b_{w}}$ & $\underset{(\mathrm{mm})}{\mathrm{d}}$ & $\begin{array}{c}\sigma_{p} \\
(M P a)\end{array}$ & $\begin{array}{c}\Phi \\
\text { (Degree) }\end{array}$ & Cables \\
\hline AD. 14.37 & 22.5 & \multirow{22}{*}{152} & 152 & \multirow{22}{*}{254} & 742 & 6.45 & 11 \\
\hline B. 14.34 & 18.2 & & \multirow{17}{*}{80} & & 805 & 0.00 & 12 \\
\hline B. 14.41 & 20.0 & & & & 805 & 0.00 & 12 \\
\hline BD. 14.18 & 43.0 & & & & 861 & 2.70 & 13 \\
\hline BD. 14.19 & 43.0 & & & & 784 & 5.00 & 12 \\
\hline BD. 14.23 & 26.6 & & & & 693 & 10.00 & 11 \\
\hline BD. 14.26 & 24.0 & & & & 812 & 10.00 & 11 \\
\hline BD. 14.27 & 24.0 & & & & 777 & 2.22 & 11 \\
\hline BD. 14.28 & 23.0 & & & & 826 & 1.53 & 11 \\
\hline BD.24.32 & 18.6 & & & & 770 & 1.88 & 11 \\
\hline BD. 14.34 & 18.0 & & & & 770 & 6.28 & 11 \\
\hline BD. 14.35 & 20.0 & & & & 770 & 2.38 & 11 \\
\hline BD. 14.42 & 26.0 & & & & 567 & 6.45 & 11 \\
\hline BV. 14.30 & 28.0 & & & & 861 & 3.25 & 11 \\
\hline BV.14.32 & 26.0 & & & & 784 & 3.25 & 12 \\
\hline BV. 14.34 & 25.0 & & & & 868 & 2.70 & 12 \\
\hline BV. 14.35 & 23.5 & & & & 805 & 5.36 & 12 \\
\hline BV. 14.42 & 20.0 & & & & 840 & 6.80 & 13 \\
\hline CD. 13.23 & 26.5 & & \multirow{4}{*}{45} & & 840 & 0.00 & 12 \\
\hline CD.13.24 & 25.0 & & & & 784 & 3.40 & 12 \\
\hline CD. 13.25 & 24.0 & & & & 826 & 2.85 & 12 \\
\hline CD.14.34 & 17.5 & & & & 735 & 1.88 & 11 \\
\hline
\end{tabular}




\section{Figure 2 - Forces acting in an inclined crack (ACl-ASCE Committee 426 (8))}

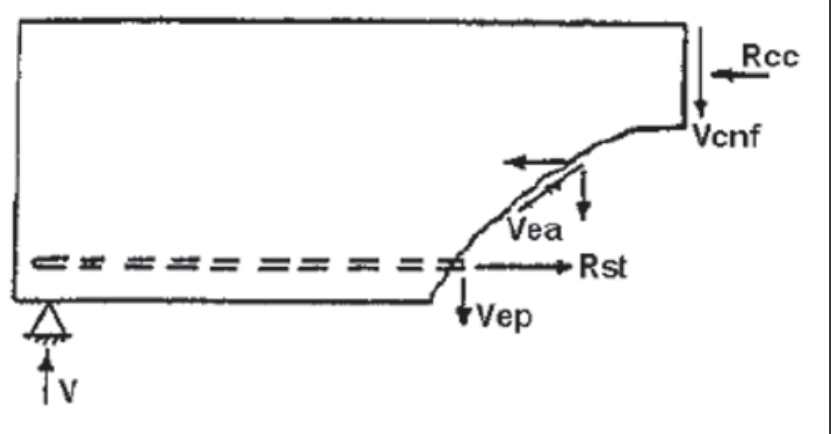

inclinations, leading to increase the tensions that cause cracks in beams with lower inclination cables.

\subsection{Shear behavior of prestressed concrete beams}

The shear bearing capacity of a prestressed concrete beam can be divided into two parts, one resisted by the concrete and its auxiliary mechanisms described ahead, and the other resisted by transverse reinforcement. A beam, even without transversal reinforcement has the ability to resist to a certain intensity of shear force. Figure 2 shows the various components of the shear resistance mechanisms of beams without transversal reinforcement, except the component related to the arc effect according to ACI-ASCE 426 Comittee [8].

For reinforced concrete structures subject to shear forces, the amount of resistance due to concrete is the sum of several mechanisms capable of transmitting forces between the sections as the effect of the non-cracked concrete, and this mechanism occurs at not fissured stretches of the beam (between two consecutive cracks) or in non-fissured parts of fissured elements (compression zone of a cracked section); the aggregate interlock that occurs between the two surfaces of a crack, and the contribution of the aggregates interlock to the shear strength depends on the opening of the crack and roughness of surfaces; the dowel action ef-

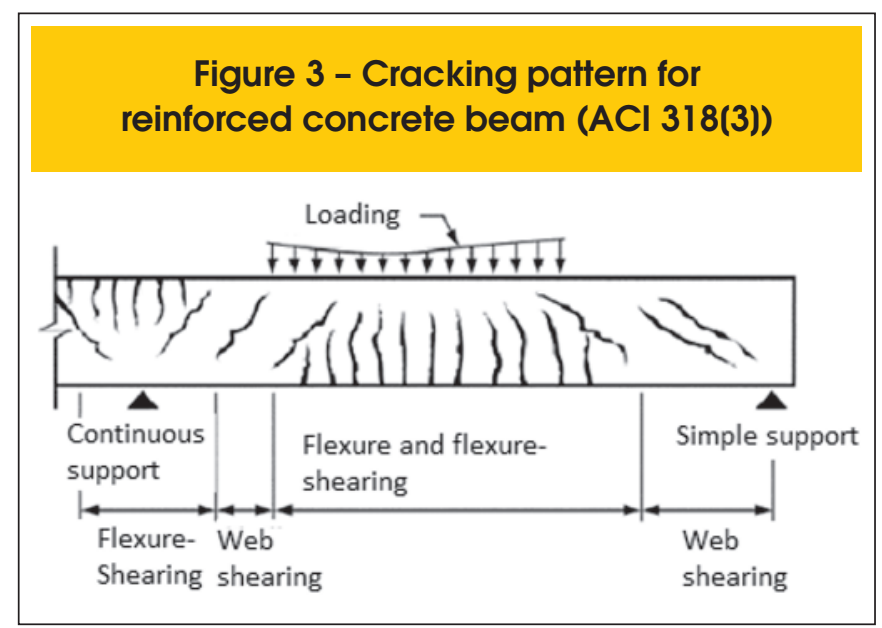

fect, where the longitudinal reinforcement resists a portion of the displacement caused by shear force due to the dowel action on the bar, and the dowel force in the longitudinal reinforcement bar depends on the bar stiffness at the intersection with the crack; and the arc effect, which is a mechanism that occurs more significantly in beams with reduced span and confers an increase in their load capacity. In the case of beams subjected to concentrated loads, the intensity of the arc effect is related to the ratio $a / d$ of the beam, where $a$ is the distance from the point of application of load to the nearest support and $d$ is the distance from the more compressed fiber of the beam to the center of gravity of the longitudinal tensile reinforcement section. Beam with ratio a/d smaller than 1 may present cracks ranging from the loading application point to the supports. These cracks prevent longitudinal reinforcement shear flow to the compression zone causing the element starts to behave like an arc and not as a beam.

\section{$2.2 \mathrm{ACl} 318$}

According to $\mathrm{ACl} 318$ [3], the shear strength of prestressed concrete beams is based on the analogy of the modified truss model, where $V_{n}$ is the nominal shear strength, obeying the condition of being greater than the design shear force in the considered section, $V_{u}$, being presented in equations 1 and 2 .

$\phi V_{n} \geq V_{u}$

$$
V_{n}=\phi \mathrm{n} V_{c}+\phi \mathrm{n} V_{s}
$$

\section{Where,}

$\phi$ : reduction factor: 0,75 ;

$V_{c}$ : concrete parcel;

$V_{s}$ : transversal reinforcement parcel.

The calculation of $V_{c}$ parcel is based on the cracking pattern shown in Figure 3 , where $V_{c i}$ force is responsible for the appearance of flexure cracks and $V_{c w}$ force by the appearance of shear cracks in the web, calculated according to the equations 3 and 4 . The value of the parcel $V_{c}$ is the lower of the two.

$V_{c i}=\left(0.05 \mathrm{n} \lambda \mathrm{n} \sqrt{f_{c}} \mathrm{n} b_{w} \mathrm{n} d_{p}+V_{d}+\frac{V_{i} \mathrm{n} M_{c r e}}{M_{\text {max }}}\right)>$
$\left(0.14 \mathrm{n} \sqrt{f_{c}} \mathrm{n} b_{w} \mathrm{n} d\right)$
$V_{c w}=\left(0.29 \mathrm{n} \lambda \mathrm{n} \sqrt{f_{c}}+0.3 \mathrm{n} f_{p c}\right) \mathrm{n} b_{w} \mathrm{n} d+V_{p}$


Where,

$\lambda$ : concrete's mechanical properties modification factor, equal to 1 ;

$f_{c}$ : concrete's compressive strength;

$b_{w}$ : beam's width;

$d_{p}$ : length between the more compressed fiber to the gravity center of the prestressed reinforcement, not less than $0,8 \cdot h$;

$V_{d}$ : shear force on the cross section due to self-weight;

$V_{i}$ : shear force on the cross section due to external loading acting with $M_{\text {max }}$;

$M_{\max }$ : maximum bending moment due to external loading;

$M_{c r e}$ : bending moment that generates flexure cracking on the cross section due to external loading;

$f_{p c}$ : concrete's compressive strength at the cross section center which resists to the external loading; $V_{p}$ : vertical component of the prestressed force.

\subsection{EUROCODE 2}

The EUROCODE 2 [4] specifies two methods for calculating the shear strength as a function of the presence or absence of transverse reinforcement. For no shear reinforcement elements (Equation 5) resistance is expressed as $V_{c}$. For elements with shear reinforcement, resistance is the higher of $V_{R d s}$ and $V_{R d, \text { max }}$, shown in equations 6 and 7 .

$$
V_{R d, c}=\left[C_{R d, c} \mathrm{n} k \mathrm{n}\left(100 \mathrm{n} \rho_{l} \mathrm{n} f_{c k}\right)^{\frac{1}{3}}+k_{1} \mathrm{n \sigma}_{c p}\right] \mathrm{n} b_{w} \mathrm{nd}
$$

$$
V_{R d, s}=\frac{A_{s w}}{s} \mathrm{n} z \mathrm{n} f_{y w d} \mathrm{n} \cot \theta
$$

$$
V_{R d, \max }=\frac{\alpha_{c w} \mathrm{n} b_{w} \mathrm{nznvn} f_{c d}}{\operatorname{cotg} \theta+\operatorname{tg} \theta}
$$

\section{With,}

$V_{R d, c}$ : design shear resistance for no shear reinforcement elements;

$V_{R d, s}:$ parcel from shear reinforcement;

$V_{R d, \text { max }}$ : concrete strut maximum strength;

$C_{R d} C$ : factor with value of $\left(0.18 / \mathrm{Y}_{\mathrm{c}}\right)$;

$k=1+\sqrt{\frac{200}{d}} \leq 2.0$, with $d$ in $\mathrm{mm}$;

$\rho_{i}$ : geometric rate of flexure reinforcement;

$k_{1}$ : factor with value of 0.15 ;

$\sigma_{c p}$ : concrete's compressive strength due to prestressing, in MPa;

$d$ : cross section useful depth, from the center of the prestressing reinforcement till the more compressed fiber, in $\mathrm{mm}$;

$A_{s w}$ : shear reinforcement cross section area;

$s:$ stirrups spacing;

$z$ : lever arm equal to $0.9 d$, with $d$ in $\mathrm{mm}$;

$f_{\text {ywd }}$ : desig yield stress of the shear reinforcement;

$v$ : 0.5 for $f_{c} \leq 60 \mathrm{MPa}$ and 0.6 for $f_{c} \geq 60 \mathrm{MPa}$, since the shear re- inforcement stress be not higher than $80 \%$ of the characteristic yield stress.

\subsection{NBR 6118}

NBR 6118 [5] presents two calculation models based on truss model analogy, associated with complementary bearing mechanisms developed within the structural element and represented by an additional component $V_{c}$. The model I considers checking the compressed diagonal $V_{R d 2}$ (Equation 8) and tensioned diagonal $V_{R d 3}$ (Equation 9). The strut inclination $\theta=45^{\circ}$ in relation to the longitudinal axis of the structural element.

$$
V_{R d 2}=0.27 \mathrm{n} \alpha_{v} \mathrm{n} f_{c d} \mathrm{n} b_{w} \mathrm{nd}
$$

$$
V_{R d 3}=V_{c}+V_{s w}
$$

\section{Where,}

$\alpha_{v}=\left(1-f_{c k} / 250\right)$;

$V_{s w}=\left(A_{s w} / s\right) \cdot 0.9 \cdot d \cdot f_{v w d}(\operatorname{sen} \alpha+\cos \alpha) ;$

$V_{c}=0$ for tensioned structural elements when the neutral axis is out of the cross section;

$V_{c}=V_{c 0}$ for simple flexure and tension-flexure with the neutral axis in the cross section;

$V_{c}=V_{c 0}\left(1+M_{d} / M_{s d \text { max }}\right) \leq 2 V_{c 0}$ for compression-flexure, with:

$V_{c o}=0.6 \cdot f_{c t d} \cdot b_{w} d$

$f_{c t d}^{c o}=f_{c t k, i n} / Y_{c}$

The model II also consider checking the compressed diagonal $V_{R d 2}$ (Equation 10) and tensioned diagonal $V_{R d 3}$ (Equation 11). In this case, the strut inclination varies between $30^{\circ}$ and $45^{\circ}$.

$$
V_{R d 2}=0,54 \mathrm{n} \alpha_{v 2} \mathrm{n} f_{c d} \mathrm{n} b_{w} \mathrm{n} d \mathrm{n} \sin ^{2} \theta(\cot \alpha+\cot \theta)
$$

$$
V_{R d 3}=V_{c}+V_{s w}
$$

Where,

$V_{s w}=\left(A_{s w} / s\right) \cdot 0,9 \cdot d \cdot f_{y w d} \cdot(\operatorname{cotg} \alpha+\operatorname{cotg} \theta) \cdot \operatorname{sem} \alpha$

$V_{c}=0$ for tensioned structural elements when the neutral axis is out of the cross section;;

$V_{c}=V_{c 1}$, for simple flexure and tension-flexure with the neutral axis in the cross section;

$V_{c}=V_{c 1}\left(1+M_{d} M_{S d, \max }\right)<2 \cdot V_{c 1}$ for compression-flexure, with:

$V_{c 1}^{c}=V_{c 0}$ when $V_{S d} \leq V_{c o}$

$V_{c 1}=0$ when $V_{S d}=V_{R d 2}$, using linear interpolation for intermediary values. 


\section{Table 3 - Current Beam's characteristics}

\begin{tabular}{|c|c|c|c|c|c|c|c|c|c|c|c|}
\hline Beam & $\underset{(\mathrm{mm})}{\mathrm{d}}$ & $\begin{array}{c}e_{p} \\
(\mathrm{~mm})\end{array}$ & $\underset{\left(\mathrm{mm}^{2}\right)}{A_{\mathrm{s}}}$ & $\underset{\left(\mathrm{mm}^{2}\right)}{\mathrm{A}_{\mathrm{p}}}$ & $\begin{array}{c}c_{s} \\
(\mathrm{~mm})\end{array}$ & $\begin{array}{c}c_{p} \\
(\mathrm{~mm})\end{array}$ & $\begin{array}{c}f_{\mathrm{ck}} \\
(\mathrm{MPa})\end{array}$ & $\begin{array}{c}E_{s} \\
(G P a)\end{array}$ & $\begin{array}{c}E_{p} \\
(G P a)\end{array}$ & $\begin{array}{c}\theta \\
\text { (Grau) }\end{array}$ & $\mathrm{Tr}$ \\
\hline VCPR-0 & \multirow{6}{*}{361} & \multirow{6}{*}{180} & \multirow{6}{*}{942} & \multirow{6}{*}{101} & \multirow{6}{*}{20} & \multirow{6}{*}{45} & \multirow{6}{*}{30} & \multirow{6}{*}{210} & \multirow{6}{*}{195} & 0 & $\mathrm{R}$ \\
\hline VCPP-O & & & & & & & & & & 16 & $\mathrm{P}$ \\
\hline VCPR-250 & & & & & & & & & & 0 & $\mathrm{R}$ \\
\hline VCPP-250 & & & & & & & & & & 16 & $\mathrm{P}$ \\
\hline VCPR-150 & & & & & & & & & & 0 & R \\
\hline VCPP-150 & & & & & & & & & & 16 & $\mathrm{P}$ \\
\hline
\end{tabular}

\section{Table 4 - Concrete's mechanical properties}

\begin{tabular}{|c|c|c|c|c|c|c|}
\hline \multirow{2}{*}{$\begin{array}{c}\text { Mechanical } \\
\text { property }\end{array}$} & \multicolumn{3}{|c|}{ Experimental } & \multicolumn{3}{|c|}{ Theoretical (NBR $6118(5))$} \\
\hline & $\begin{array}{l}f_{c, \exp } \\
(M P a)\end{array}$ & $\begin{array}{l}f_{\text {ct exp }} \\
\text { (MPa) }\end{array}$ & $\begin{array}{l}E_{\text {sec, exp }} \\
\text { (GPa) }\end{array}$ & $\begin{array}{l}f_{c, \text { teor }} \\
(\mathrm{MPa})\end{array}$ & $\begin{array}{l}f_{c \text { fit too }} \\
(\mathrm{MPa})\end{array}$ & $\begin{array}{l}E_{\text {sec, teo }} \\
\text { (GPa) }\end{array}$ \\
\hline Compressive strength & 31.0 & - & - & \multirow{3}{*}{30.0} & \multirow{3}{*}{2.0} & \multirow{3}{*}{26.1} \\
\hline Tensile strength & - & 3.01 & - & & & \\
\hline Elastic modulus & - & - & 25.0 & & & \\
\hline
\end{tabular}

\section{Experimental program}

\subsection{Beams' characteristics}

Six prestressed concrete beams using the system with greased cable and with two layouts for the prestressing cables, straight and parabolic, and variations in the shear reinforcement ratio (vertical stirrups) were tested and analyzed. The beams had cross section of $(150 \mathrm{x}$ 450) $\mathrm{mm}^{2}$, length of $2400 \mathrm{~mm}$ and $2000 \mathrm{~mm}$ of tested span, same longitudinal reinforcement and mechanical properties of the concrete (same concreted). From the six beams, three had straight cables and three parabolic ones, with one beam of each group presenting transverse reinforcement only at the supports and load application points, and the other had stirrups of diameter $5.0 \mathrm{~mm}$ each $250 \mathrm{~mm}$ and 150 $\mathrm{mm}$. The positions of the straight and parabolic cables and its inclinations were the same enabling comparisons between beams with same shear reinforcement and cables' layout. Thus, the influence of

\section{Table 5 - Properties of steel bars with diameter of $5.0 \mathrm{~mm}$ and $20.0 \mathrm{~mm}$}

\begin{tabular}{ccccc|}
$\begin{array}{c}\phi \\
(\mathrm{mm})\end{array}$ & $\begin{array}{c}\mathrm{f}_{y s} \\
(\mathrm{MPa})\end{array}$ & $\begin{array}{c}\mathrm{f}_{u} \\
(\mathrm{MPa})\end{array}$ & $\begin{array}{c}\varepsilon_{y s} \\
(\%)\end{array}$ & $\begin{array}{c}\mathrm{E}_{s} \\
(\mathrm{GPa})\end{array}$ \\
\hline 5.0 & 597.0 & 602 & 4.6 & 229.6 \\
20.0 & 580.0 & 623 & 2.8 & 207.1 \\
\hline
\end{tabular}

the cables' layout in the shear resistance was assessed by comparing the experimental results of the beams VCPR-0 and VCPP-0, VCPR250 and VCPP-250, VCPR-150 and VCPP-150. Assuming that the greater the force applied to the cable will be greater this increase in shear resistance, the cable was loaded to its permissible limit of tension to show its influence. Table 3 and Figure 4 bring the features and details of the prestressed concrete beams.

\subsection{Concrete's mechanical properties}

The compressive strength, tensile strength and elastic modulus of concrete were obtained experimentally by compression of cylindrical proofs molded according to NBR 5738 [9] at the same of the beams' concrete placement, removing three cylindrical proofs with $150 \mathrm{~mm}$ diameter and $300 \mathrm{~mm}$ length to perform each of the tests mentioned, totaling nine proofs. Determination of compressive strength followed the established by NBR 5738 [9] and the determination of tensile strength by diametrical compression followed established by NBR 7222 [10] and the secant modulus of elasticity was found according to NBR 8522 [11]. Table 4 presents the results of the mechanical properties of concrete.

\subsection{Reinforcements' mechanical properties}

The average values of the yield and failure stresses, yield strain and elastic modulus of the six steel bars samples with diameter of $20.0 \mathrm{~mm}$ and $5.0 \mathrm{~mm}$ of the flexural and transversal reinforcements, respectively, are presented in table 5. Additionally, all 


\section{Figure 4 - Beams' details}
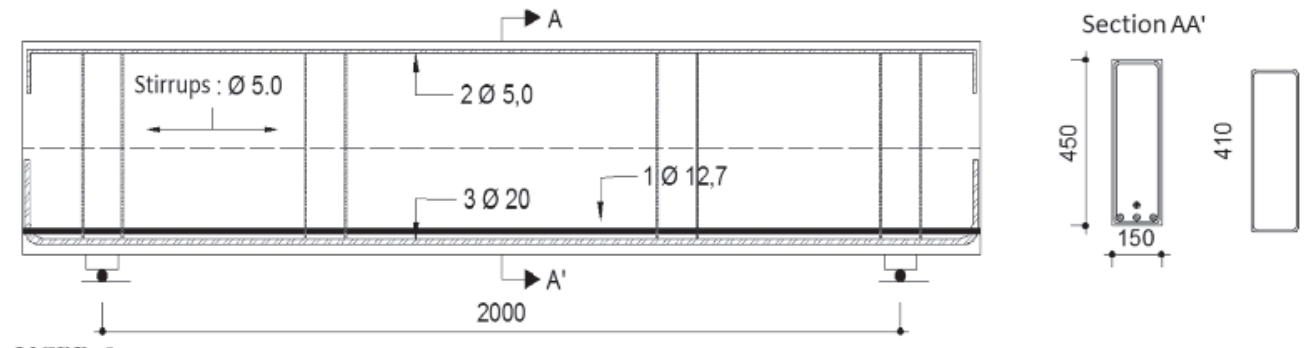

VCPR-0

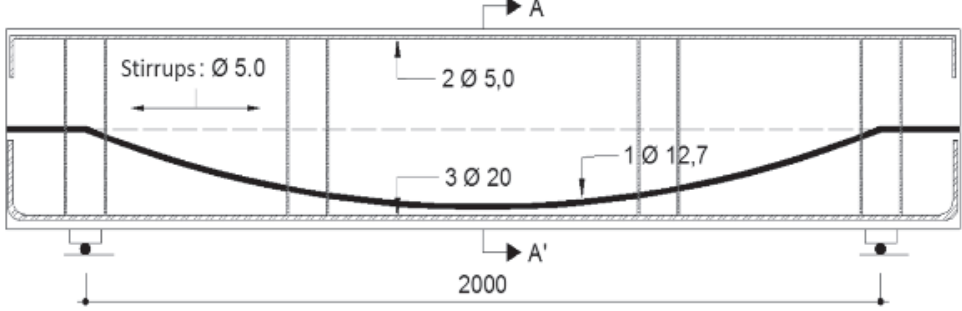

VCPP-0

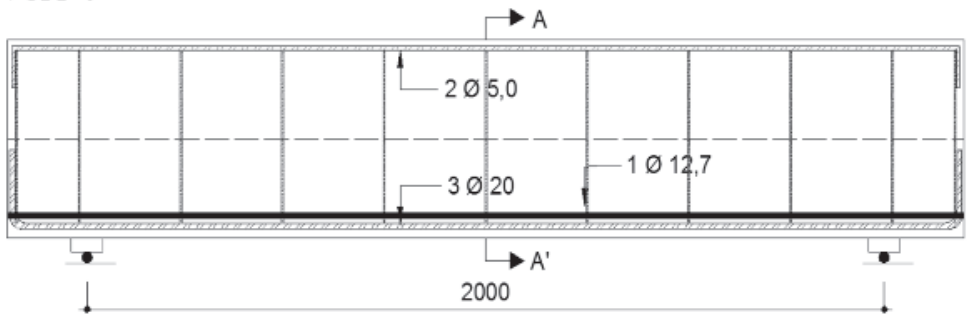

VCPR-250

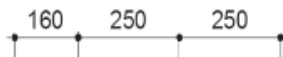

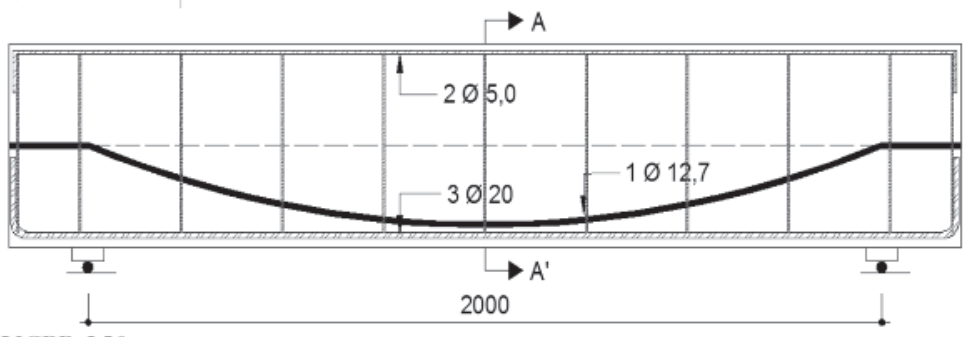

VCPP-250

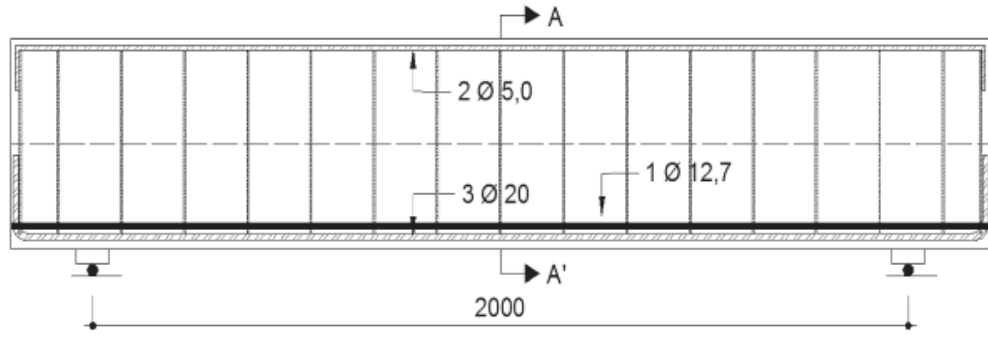

VCPR-150

$.90,150,150,150,150$.

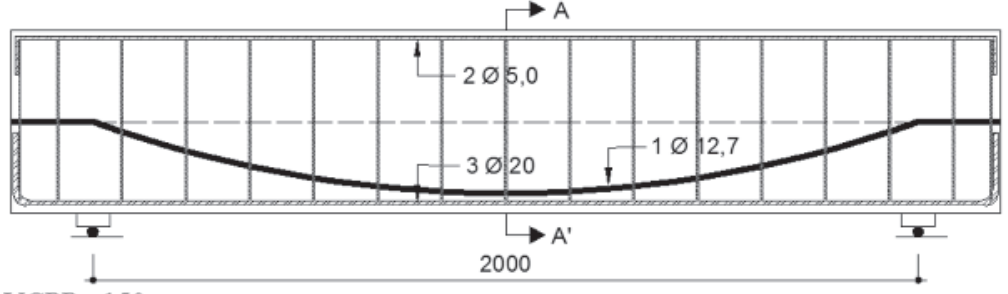

VCPP - 150 


\begin{tabular}{|c|c|}
\hline \multicolumn{2}{|c|}{$\begin{array}{c}\text { Table 6- Greased monocable's } \\
\text { mechanical properties }\end{array}$} \\
\hline Nominal diameter (mm) & 12.7 \\
\hline Cross section area $\left(\mathrm{mm}^{2}\right)$ & 101.0 \\
\hline Elastic modulus $\left(\mathrm{kN} / \mathrm{mm}^{2}\right)$ & 203.0 \\
\hline Tension strength limit (kN) & 187.0 \\
\hline Maximum prestressing force $(\mathrm{kN})$ & 150.0 \\
\hline Anchorages force $(\mathrm{kN})$ & 131.0 \\
\hline
\end{tabular}

samples met the criteria of ductility of NBR 7480 [12], which prescripts the failure stress $f_{u}$ at least equal to $1.10 \cdot f_{y s}$. The mechanical properties of the prestressed cables came from catalog of the manufacturer CIA Siderurgica Belgo Mineira and are presented in Table 6.

\subsection{Beams' production}

After making the wooden formwork and application of mold release oil, the active and passive reinforcement received spacers and were positioned carefully aiming the standardization of concrete cover of reinforcements and, consequently, the useful heights of the beams. Both the beams with straight cable and the beams with parabolic cable adopted a concrete cover of $50 \mathrm{~mm}$ from the central point of the cable to the bottom surface of the beams. The beams and proofs were then concreted at the same time and using the same concrete, being released and vibrated with immersion vibrators with diameter of $32 \mathrm{~mm}$ for beams and $25 \mathrm{~mm}$ for proofs and, after 4 hours, beams were covered with wet tissues. The mold removing happened 7 days after concrete placement. Figure 5 shows the production process of the beams.

\subsection{Instrumentation}

For monitoring the behavior of the beams along the test procedure, strain gages were used in concrete, flexural and transverse

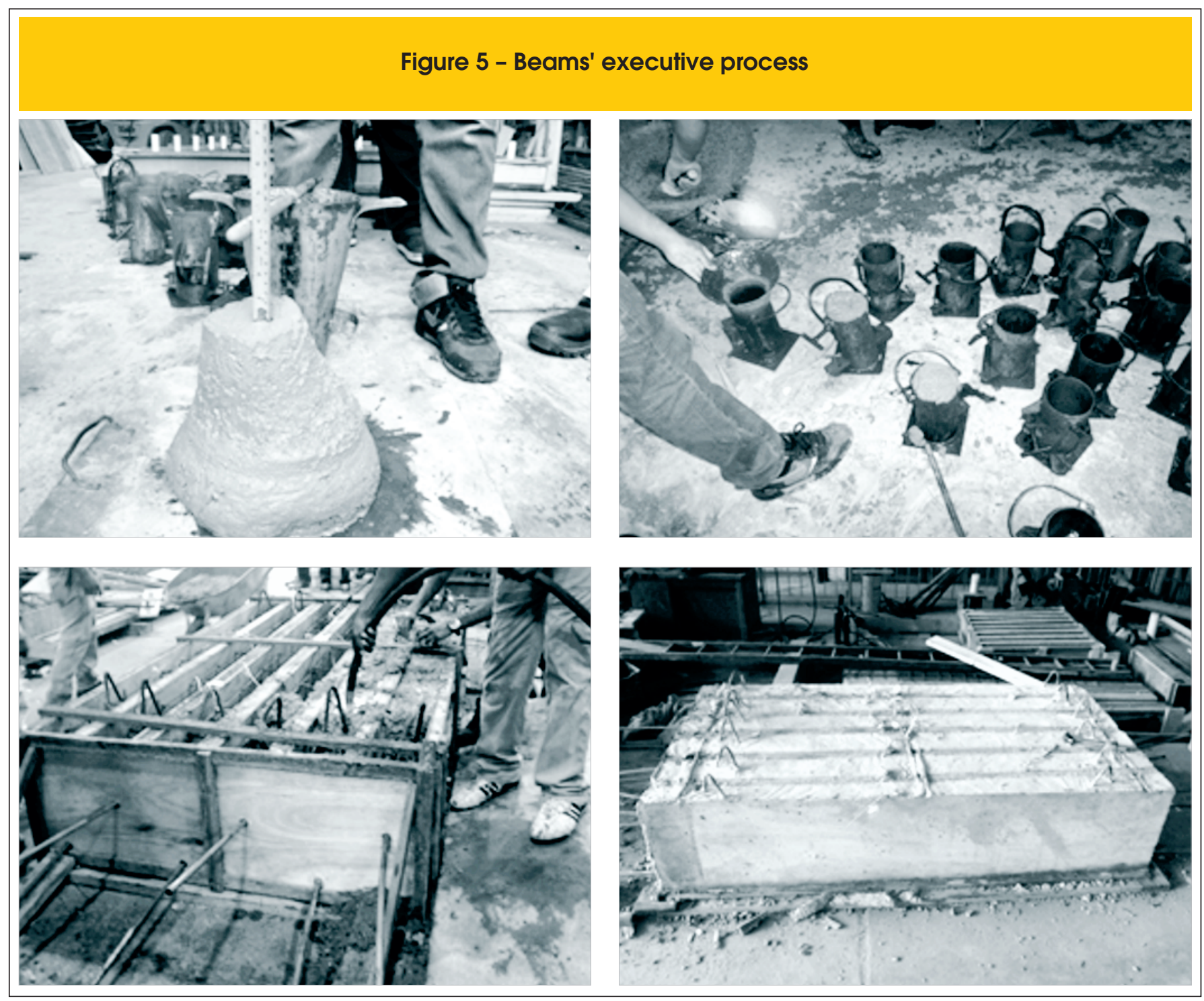


reinforcements. There were. 28 strain gages on steel bars, including passive and transverse reinforcements, 06 strain gages on concrete and 06 strain gages on the compressive reinforcement totaling 40 strain gages, and 01 dial gage per beam for observation of the evolution of vertical displacements generated by prestressing and external loadings. Figure 6 shows the instrumentation of the beams.

\subsection{Test system}

The test of the beams was carried out in the Civil Engineering Lab-

\section{Figure 6 - Instrumentation of the beams with parabolic layout cables}
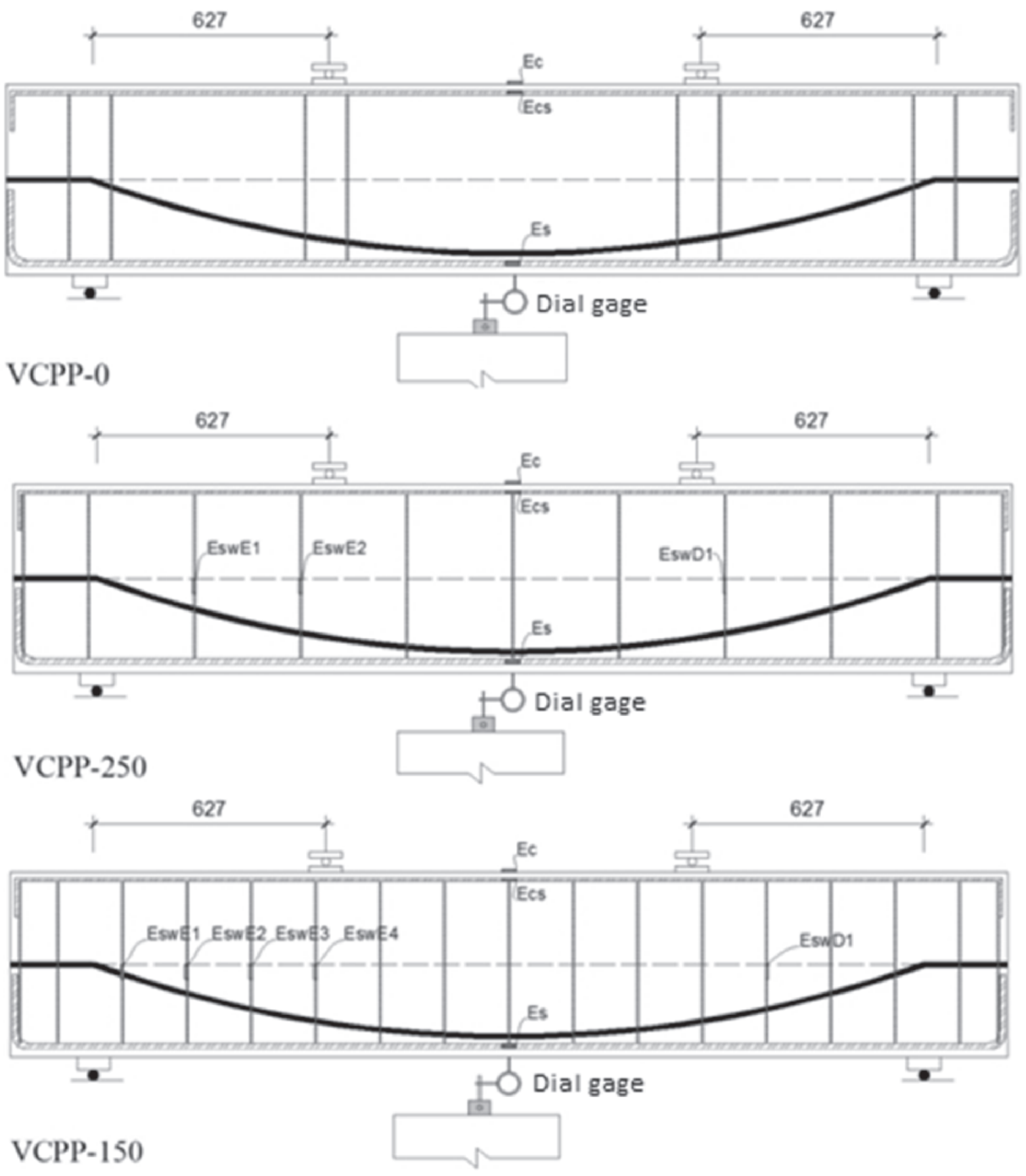
Figure 7 - Teste system

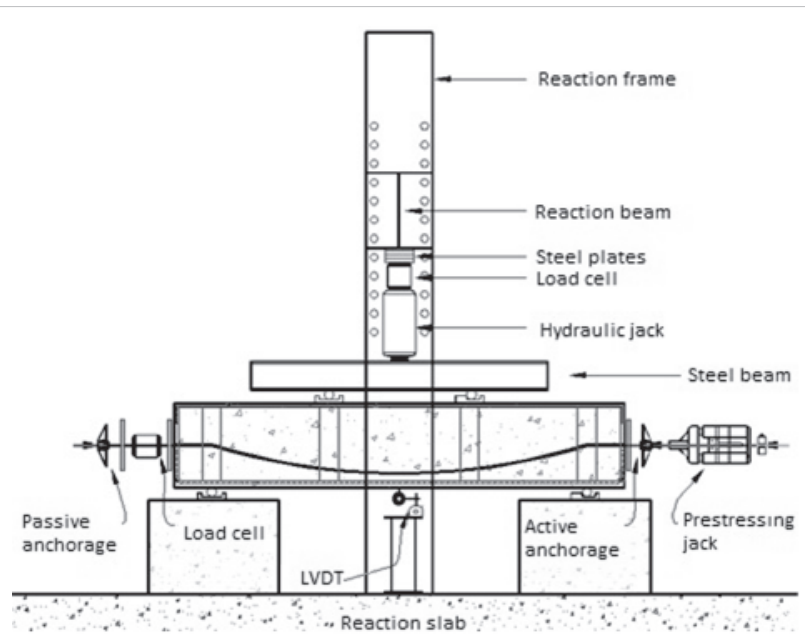

oratory of the Federal University of Para. The first step was to set up the four-point test system (Stuttgart test), positioning the beams on supports of first and second gender mounted on concrete blocks which were supported on the laboratory reaction slab. Then the data acquisition system ALMEMO ${ }^{\circledR}$ 5690-2M, from Ahlborn compatible with the AMR WinControl software was connected to all the gages of the beam, followed by mounting of the hydraulic jack and of the load cell in the reaction frame and in the passive anchoring of the beam.

The test starts with the cable tension. The prestressing was applied through a monocable hydraulic jack with capacity of 200 $\mathrm{kN}$, increments of $10 \mathrm{kN}$ until the final loading of $120 \mathrm{kN}$, after all the losses. Initially the cable was pulled up to $150 \mathrm{kN}$, anticipating losses due to the small size of the beams, for accommodation of the wedge and reinforcement slip, which ranged from $30 \%$ to $41 \%$. After these losses, there was a need of prestressing increment. The prestressing increment consisted in pull the

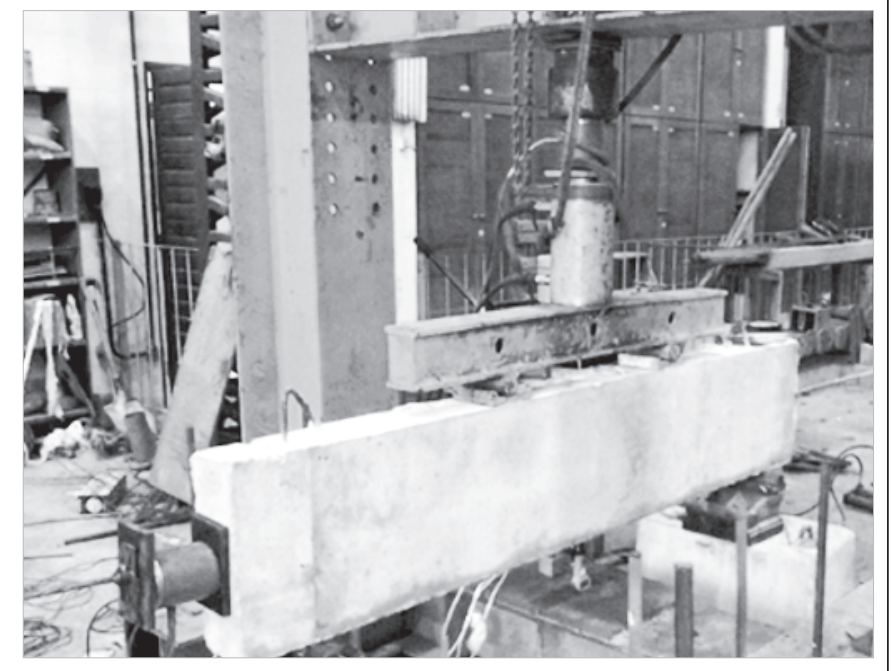

cable up to $150 \mathrm{kN}$. With the cable tensioned, the anchor was loose from the steel plate leaving a gap, which was filled with small plates to prevent the return of the anchor and the consequent loss of strength in the cable. This control was visual and this procedure was considered satisfactory when the gap was no longer visible.

Immediately after the prestressing step, began the external loading application on the beams. The loadings on the beam were applied at two equidistant points, featuring as a four-point test applied by a hydraulic jack with capacity of $1000 \mathrm{kN}$, which reacted under the beam of the reaction frame of the laboratory. The hydraulic jack applied loading until the beam's failure through a steel beam that transferred this loading to two points on the beam. The monitoring of the applied loading was made by a standard load cell of $1000 \mathrm{kN}$ and precision of $1 \mathrm{kN}$, connected to a load cell reader to indicate the magnitude of the loading. Figure 7 shows the test system.

\section{Table 7- Prestressing forces and losses}

\begin{tabular}{|c|c|c|c|c|c|c|c|c|}
\hline \multirow[b]{2}{*}{ Beam } & \multicolumn{2}{|c|}{ Prestressing } & \multirow{2}{*}{$\begin{array}{l}\text { Prestressing } \\
\text { immediate } \\
\text { loss (\%) }\end{array}$} & \multicolumn{2}{|c|}{ Represtressing } & \multirow{2}{*}{$\begin{array}{l}\text { Represtressing } \\
\text { immediate } \\
\text { loss (\%) }\end{array}$} & \multirow{2}{*}{$\begin{array}{c}P_{0} \\
(k N)\end{array}$} & \multirow{2}{*}{$\begin{array}{c}\mathrm{P}_{\mathrm{OF}} \\
(\mathrm{kN})\end{array}$} \\
\hline & $\begin{array}{l}P_{\mathrm{pi}} \\
(\mathrm{kN})\end{array}$ & $\stackrel{P_{p 0}}{(k N)}$ & & $\underset{(k N)}{P_{r i j}}$ & $\begin{array}{c}P_{F} \\
(k N)\end{array}$ & & & \\
\hline VCPR-O & 149 & 105 & 29,6 & 152 & 119 & 21,7 & 113,0 & 129 \\
\hline VCPP-O & 148 & 88 & 40,5 & 150 & 125 & 16,6 & 124,0 & 135 \\
\hline VCPR-250 & 152 & 102 & 32,9 & 151 & 121 & 19,9 & 120,5 & 127 \\
\hline VCPP-250 & 151 & 91 & 39,7 & 149 & 115 & 22,8 & 114,0 & 136 \\
\hline VCPR-150 & 150 & 109 & 27,3 & 149 & 118 & 27,5 & 117,0 & 124 \\
\hline VCPP-150 & 150 & 84 & 44,0 & 150 & 121 & 19,3 & 118,0 & 137 \\
\hline
\end{tabular}




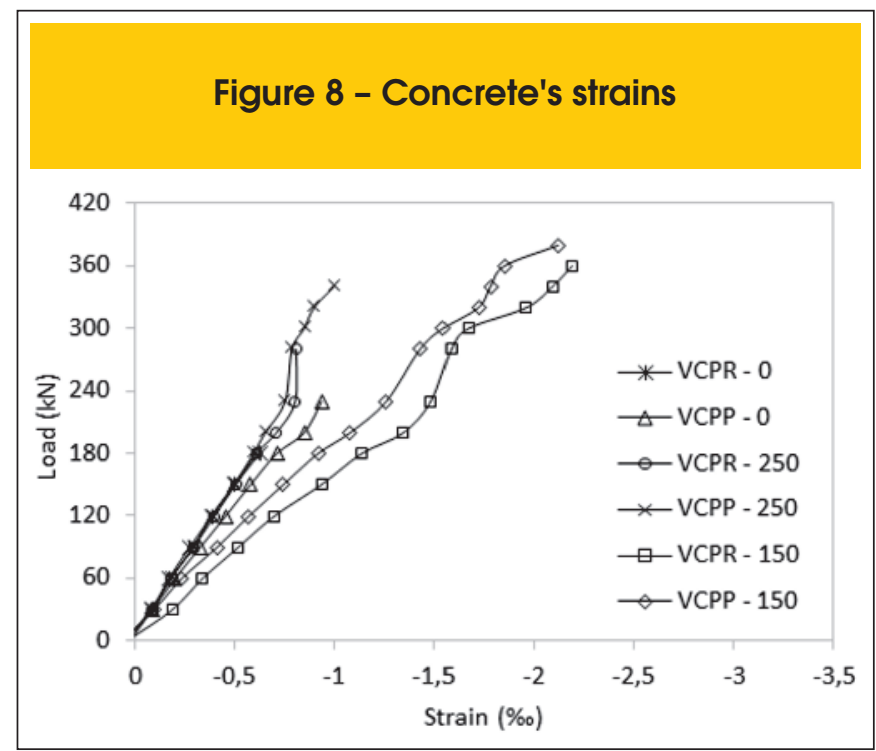

\section{Results and discussions}

\subsection{Prestressed forces and immediate losses}

The parabolic cables presented the highest variations of the prestressing forces (beams VCPP-0, VCPP-250 and VCPP-150) due to the cables' deflections, with immediate average loss of $41.4 \%$, higher than the cables with straight profile (VCPR-0, VCPR-250 and VCPR-150), which had mean immediate losses in the order of $29.9 \%$. Losses reached this amount due to the small size of the beams, high prestressing force in the cable and the manual method of crimping wedge (wedge accommodation). The small size and high prestressing force in the cable caused the high stress on anchorages requiring a larger work of wedges, increasing its accommodation. After additional prestressing the average loss was between $23 \%$ and $19.5 \%$ for the beams with straight and parabolic cables, respectively. It was also noted that during application of the loading on the beam, there was a gradual increase in force in the prestressing cable, with the largest increases observed in beams with parabolic cable. Table 7 presents the values of the forces applied in all cables of the six beams along the prestressing process as well as the immediate loss values.

\subsection{Concrete's strains}

It was observed that the stresses on the concrete surfaces were reversed along the prestressing process, creating tension at the top surface, very close to the tensile strength of concrete, and compression (-7.4 MPa) at the bottom surface. The highest tensile strain measured at the top surface of the beam, were $0.044 \%$, $0.060 \%$, $0.045 \%$, $0.07 \%$, 0.038 $\% 0.065 \%$ for the beams VCPR-0, VCPP-0, VCPR-250, VCPP-250, VCPR-150, VCPP-150, respectively. During the testing of beams, none of them exceeded the conventional limit of strain for concrete in flexure according to NBR 6118 [5], $3.5 \%$, then there was no crushing of concrete. Figure 8 shows the strains measured by the concrete's strain gage.

\subsection{Flexure reinforcement's strains}

There was no steel yielding in any of the six beams' passive flexure

\section{Figure 9 - Longitudinal flexure reinforcement strains}

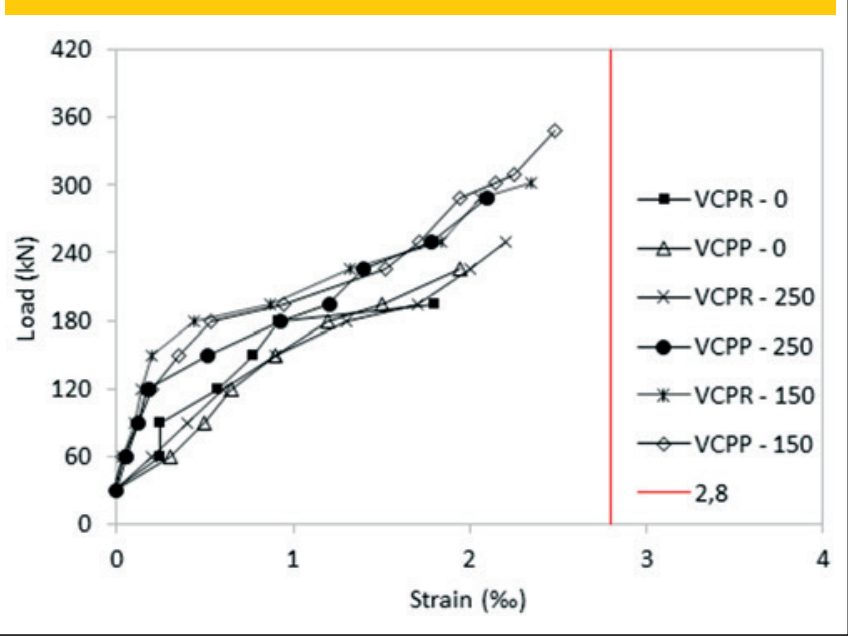

reinforcement, despite the higher failure loads of the beams. This is due to the contribution of active reinforcement in flexure strength of the beams, since the prestressing cables are from special steel having tensile strength value of $187 \mathrm{kN}$. The highest tensile strain in the passive longitudinal reinforcement bars in the middle section of the span were $1.8 \%, 1.94 \%, 2.2 \%, 2.1 \%$, $2.34 \%, 2.48 \%$ for the beams VCPR-0, VCPP-0, VCPR-250, VCPP-250, VCPR- 150, VCPP-150, respectively. Figure 9 shows the load versus deformation diagram for passive flexure reinforcement.

\subsection{Shear reinforcement's strains}

It is important to note that the beams VCPR-0 and VCPP-0 had transverse reinforcement only in supporting and load application points to avoid located rupture, and therefore not monitored, so only the beams VCPR-250, VCPP-250, VCPR-150 and VCPP150 received strain gages. Figure 10 shows the load versus strain curve for transverse reinforcement. In all the beams strains were not greater than the yield strain $\varepsilon_{y s}=4.6 \%$. The most requested stirrups were the closest to the loading, indicating that the path of stresses occurred in a lower slope flow. According to Leonhardt and Monnig [2] the longitudinal prestressing introduces in reinforced concrete elements compressive stresses that contribute to reducing tensile stresses (which are more inclined in relation to the element's axis), so that shear cracking are configured with lower inclination, with the struts reduced to values between $15^{\circ}$ and $30^{\circ}$.

\subsection{Vertical displacements}

The vertical displacements of the prestressed beams were measured by dial gages located at the middle spans of the beams and are shown in Figure 11. The eccentricity of the prestressing forces helped to reduce these displacements. At the time of prestressing were measured vertical displacements of $-0.32 \mathrm{~mm},-0.20 \mathrm{~mm}$, $-0,35 \mathrm{~mm},-0,43 \mathrm{~mm},-0,32 \mathrm{~mm},-0,37 \mathrm{~mm}$ for beams VCPR-0, VCPP-0, VCPR-250, VCPP-250, VCPR-150 and VCPP-150. 
Table 8 - Ultimate loads and failure modes

\begin{tabular}{|c|c|c|c|c|c|c|}
\hline Beam & $\underset{\left(\mathrm{mm}^{2}\right)}{\mathrm{A}_{\mathrm{s}}}$ & $\underset{\left(\mathrm{mm}^{2}\right)}{A_{\mathrm{sp}}}$ & $\underset{\left(\mathrm{mm}^{2}\right)}{A_{\mathrm{sw}}}$ & $\begin{array}{c}\mathrm{s} \\
(\mathrm{mm})\end{array}$ & $\underset{(\mathrm{kN})}{\mathrm{P}_{u}}$ & Failure mode \\
\hline VCPR-O & \multirow{6}{*}{942} & \multirow{6}{*}{101} & - & - & 194.4 & \multirow{6}{*}{ Shearing } \\
\hline VCPP-0 & & & - & - & 225.1 & \\
\hline VCPR-250 & & & \multirow{4}{*}{39.3} & 250 & 249.9 & \\
\hline VCPP-250 & & & & 250 & 288.5 & \\
\hline VCPR-150 & & & & 150 & 302.2 & \\
\hline VCPP-150 & & & & 150 & 348.3 & \\
\hline
\end{tabular}

\subsection{Ultimate loads and failure modes}

During the tests, none of the six tested beams reach the passive longitudinal reinforcement's yield loading, as expected, failing by shearing. Table 8 presents the values of the latest experimental loads and failure modes of the beams. It was clear the influence of the inclined cable on the shear strength of the beams. The vertical component generated by the prestressing forces in the parabolic cables provided greater resistant capacity with increases of up to $15 \%$ for the beams with stirrups spaced each $150 \mathrm{~mm}$. Parabolic

\section{Figure 10 - Beams' stirrups strains}
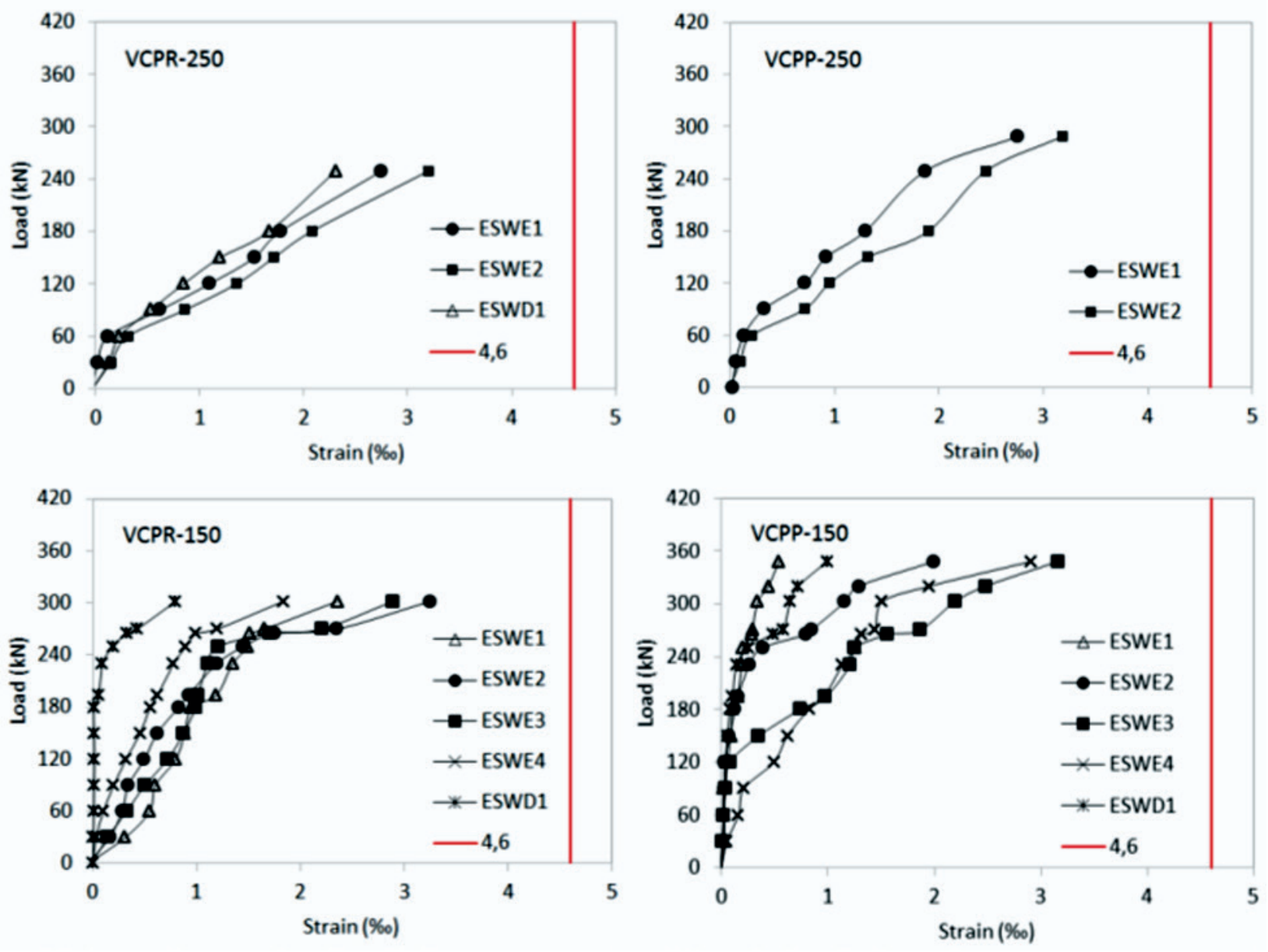


\section{Table 9 - Theoretical and experimental results}

\begin{tabular}{|c|c|c|c|c|c|c|c|}
\hline \multirow[b]{2}{*}{ Beam } & \multirow{2}{*}{$\begin{array}{l}P_{\text {fiex }} \\
(\mathrm{kNN})\end{array}$} & \multicolumn{2}{|c|}{ NBR $6118(5)$} & \multicolumn{2}{|c|}{ ACl $318(3)$} & \multirow{2}{*}{$\begin{array}{c}\text { Eurocode } 2 \text { (2) } \\
\text { EC2 } \\
(\mathrm{kN})\end{array}$} & \multirow{2}{*}{$\begin{array}{l}\text { Experimental } \\
\qquad \mathrm{P}_{u} \\
(\mathrm{kN})\end{array}$} \\
\hline & & $\begin{array}{l}\text { MOD. I } \\
(\mathrm{kN})\end{array}$ & $\begin{array}{l}\text { MOD. II } \\
\text { (kN) }\end{array}$ & $\begin{array}{l}\mathrm{ACl} F S \\
(\mathrm{kN})\end{array}$ & $\begin{array}{l}\text { ACI WS } \\
(\mathrm{kN})\end{array}$ & & \\
\hline VCPR-O & \multirow{6}{*}{341.2} & 177.4 & 177.4 & 179.9 & 269.5 & 181.8 & 194.4 \\
\hline VCPP-O & & 242.7 & 242.7 & 246.1 & 269.5 & 248.0 & 225.1 \\
\hline VCPR-250 & & 237.3 & 281.1 & 246.4 & 335.9 & 119.7 & 249.9 \\
\hline VCPP-250 & & 302.6 & 346.4 & 312.6 & 335.9 & 185.8 & 288.5 \\
\hline VCPR-150 & & 277.2 & 350.2 & 290.8 & 380.3 & 199.5 & 302.2 \\
\hline VCPP-150 & & 342.5 & 415.5 & 356.9 & 380.3 & 265.6 & 348.3 \\
\hline
\end{tabular}

cables showed greater strength gains at the end of the tests, $15 \%$ against $8 \%$ of straight cables. This may have contributed to combat tensile stresses generated by struts and to increase the aggregate interlock close to ultimate loadings. Figure 12 shows the final aspect of the beams.

\section{Codes' prescriptions analysis}

Table 9 presents the theoretical results for shear resistance according to the codes ACI 318 [3], EUROCODE 2 [4] and NBR 6118 [5] and the experimental results obtained from tests of the six prestressed beams, and Table 10 presents the relationship between experimental ultimate load $\left(P_{U}\right)$ and predicted ultimate load $\left(P_{E}\right)$. The ACI 318 method [3] is based on the average shear stress and the total depth of the cross section $b_{w} \cdot d$. The parcel $V_{c}$ in prestressing must be the lower of $V_{c i}$ and $V_{c w}$ which are, respectively, failure by flexure-shearing (ACI FS) and web shear failure (ACI WS). Besides the concrete contribution is also taken into account the parcel related to shear reinforcement $V_{s}$. To the beams with straight cable (VCPR-0, VCPR-250 and VCPR-150), the estimated results for the ACI FS method showed relations $P_{U} / P_{E}$ equal to 1.08, 1.01, 1.04 , and the beams with parabolic cable (VCPP-0, VCPP-250 and VCPP-150) with relationship $P_{J} / P_{E}$ equal to $0.91,0.92$ and 0.98 , respectively. The method does not consider directly the contribution of horizontal component $V_{p}$. Prestressing is taken into account by a moment which cancels the design external moment, which depends on the prestressing cable eccentricity in relation to the neutral axis. But in the method based on the failure mode by web shearing (ACI WS), the favorable effect of the vertical component is taken into consideration in the equation. By this method the beams with straight cable presented relationship $P_{U} / P_{E}$ equal to $0.72,0.74$ and 0.92 , respectively, and beams with parabolic cable had relationship $P_{\mathcal{J}} / P_{E}$ equal to $0.84,0.86$ and 0.79 , respectively. As the ICA recommends the lower value between $V_{c i}$ and $V_{c w}$ for the concrete parcel in the shear strength, in all beams the value used was $V_{c i}$

The procedure of EUROCODE 2 [4] considers beams with shear reinforcement and the resistance is based on the truss model with variation of the strut angle inclination, and for beams without shear reinforcement only the concrete's contribution. For beams with shear reinforcement the European code defines resistance as the lower of the parcels from shear reinforcement, $V_{R d s}$, and the maximum limit value for strut crushing, $V_{R d, \text { max }}$, without the concrete's contribution to the resistance. For without shear reinforcement elements, prestressing is considered through the prestressing tension $\sigma_{c p}$. The relationship $P_{U} / P_{E}$ for the beams with straight cable (VCPR-0, VCPR-250, VCPR-150) was 1.07, 2.09 and 1.51, respectively, and the beams with parabolic cable (VCPP-0, VCPP-250, VCPP-150) this relationship was 0.91, 1.55 and 1.31 , respectively.

NBR 6118 [5] considers two calculation formulations based on the truss model and the failure of tensioned and compressed diagonals. Model I considers the strut inclination of $45^{\circ}$ and inclination of the stirrups between $45^{\circ}$ and $90^{\circ}$. The Model II considers the strut inclination ranging between $30^{\circ}$ and $45^{\circ}$ and the same variation of the stirrups inclination of Model I. The favorable effect of prestressing is taken into consideration in the relationship between the bending moment annulling the normal compressive stresses in cross section surface $\left(M_{0}\right)$, and the design bending moment, maximum in the section in question, which can be taken as the

\section{Figure 11 - Beams' vetical displacements}

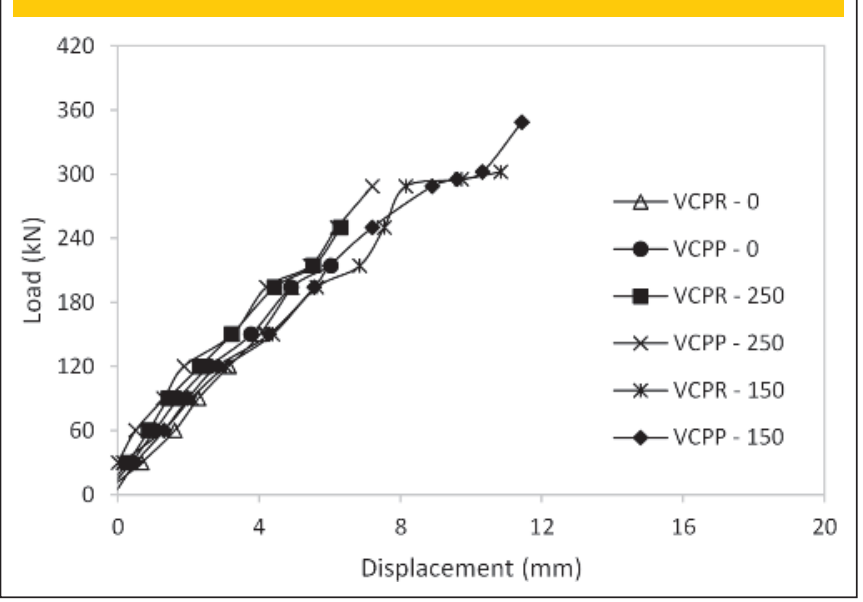


Figure 12 - Beams' final aspect
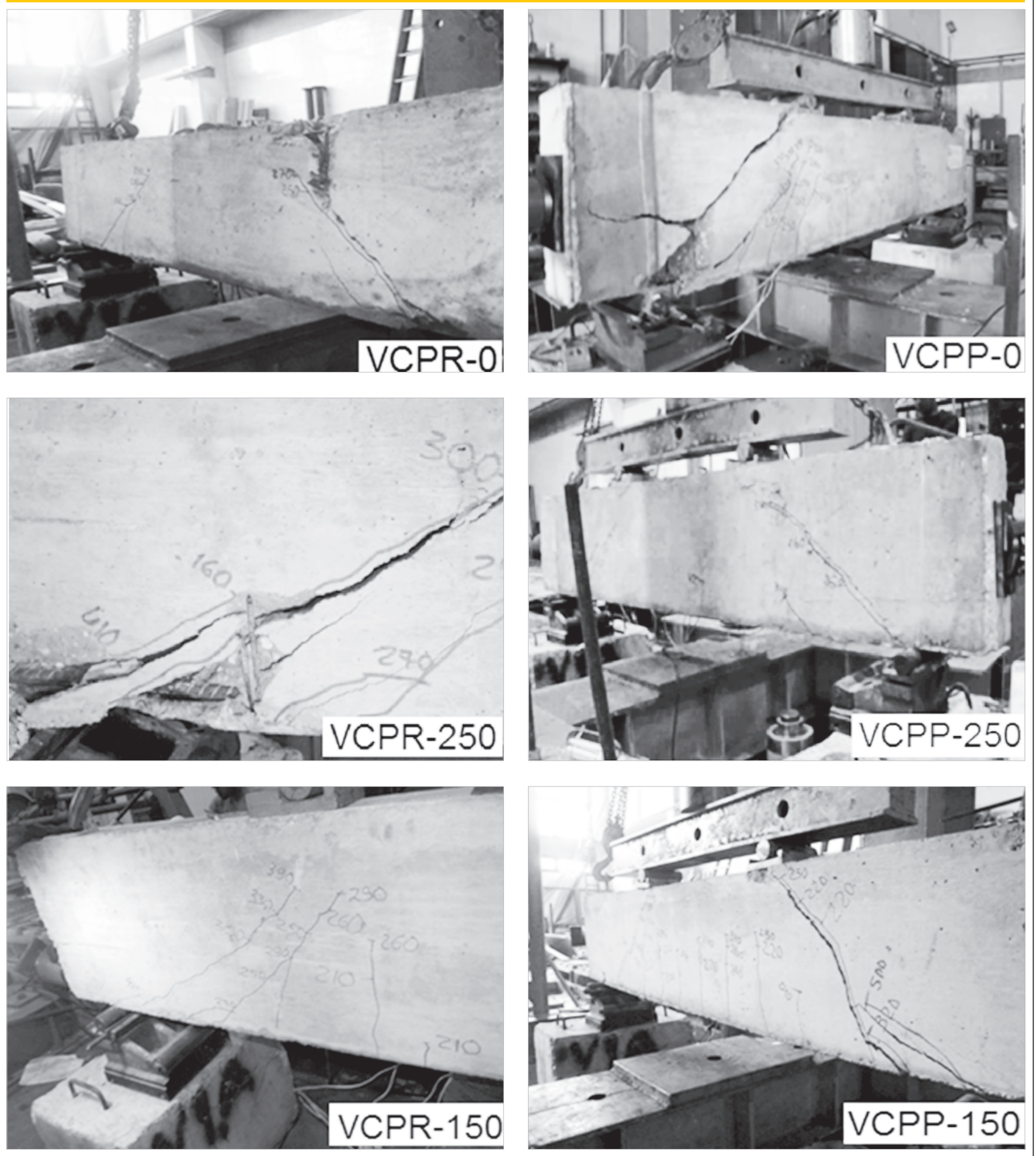


\section{Table 10 - Variation of $P_{U} / P_{E}$ relationship}

\begin{tabular}{|c|c|c|c|c|c|}
\hline \multirow[b]{2}{*}{ Beam } & \multicolumn{2}{|c|}{ NBR 6118 (2014) } & \multicolumn{2}{|c|}{$\mathrm{ACl} 318$} & \multirow{2}{*}{$\begin{array}{c}\text { Eurocode } 2 \\
P_{u} / P_{E} \\
E C 2\end{array}$} \\
\hline & $\begin{array}{c}P_{u} / P_{E} \\
\text { MÖD. I }\end{array}$ & $\begin{array}{c}P_{\mathrm{u}} / \mathrm{P}_{\mathrm{E}} \\
\text { MOD. II }\end{array}$ & $\begin{array}{l}\mathrm{P}_{\mathrm{u}} / \mathrm{P}_{\mathrm{E}} \\
\mathrm{ACl} \mathrm{FS}\end{array}$ & $\begin{array}{c}\mathrm{P}_{\mathrm{H}} / \mathrm{P}_{\mathrm{E}} \\
\mathrm{ACl} \text { WS }\end{array}$ & \\
\hline VCPR-0 & 1.10 & 1.10 & 1.08 & 0.72 & 1.07 \\
\hline VCPP-O & 0.93 & 0.93 & 0.91 & 0.84 & 0.91 \\
\hline VCPR-250 & 1.05 & 0.89 & 1.01 & 0.74 & 2.09 \\
\hline VCPP-250 & 0.95 & 0.83 & 0.92 & 0.86 & 1.55 \\
\hline VCPR-150 & 1.09 & 0.86 & 1.04 & 0.79 & 1.51 \\
\hline VCPP-150 & 1.02 & 0.84 & 0.98 & 0.92 & 1.31 \\
\hline
\end{tabular}

greatest value of the considered length. The relationships $P_{J} / P_{E}$ for Model I and for the beams with straight cables (VCPR-0, VCPR250, VCPR-150) were 1.10, 1.05 and 1.09, respectively, and for the beams with parabolic cables (VCPP-0, VCPP-250, VCPP-150) the values were $0.93,0.95$ and 1.02 , respectively. For Model II and beams with straight cables, the relationships $P_{J} / P_{E}$ were $1.10,0.89$ and 086 , and for the beams with parabolic cables were $0.93,0,83 \mathrm{e}$ 0.84 , respectively.

The trend against the safety of NBR 6118 and $\mathrm{ACl}$ codes estimates, i.e. using the Model II of NBR 6118 and the equation of $\mathrm{ACl}$ considering the predominance of shear in the web (ACI WS), may be associated with the theoretical imprecision and/or experimental on account of the strut inclination $\left(30^{\circ}\right)$ and the vertical component of prestressing, respectively. However, these guidelines recommend that the lowest values are adopted, with the result that their estimates were accurate, i.e. Model I of NBR 6118 and considerations $\mathrm{ACl}(\mathrm{ACl} F \mathrm{~S})$ for flexural-shear $\mathrm{ACl}(\mathrm{ACl} F \mathrm{~F})$.

\section{Conclusions}

Several aspects of the prestressed system development were discussed in this paper, as the contribution of the prestressing cable's layout on the shear strength of beams, the influence of prestressing in reducing vertical displacements and cracks, transverse and longitudinal reinforcement's strains, concrete strains, beyond comparisons of experimental results with the results estimated by the standards ACI 318 [3], EUROCODE 2 [4] and NBR 6118 [5]. For the presented experimental results it can be concluded that the parabolic layout of the cable raised up to $16 \%$ the shear strength of beams, with or without stirrups. Already the codes' estimates differed among themselves with some results against safety, but still close and consistent with the experimental results obtained in this study, except the results of EUROCODE 2 to the beams with stirrups where estimates were too conservatives. It emphasizes the need for more experiments and detailed analyzes (computing, database, etc.) to enable a better understanding of the problem and a more fair assessment of the codes' estimates.

\section{Acknowledges}

The authors thank CNPq, IPEAM and CAPES for financial support at all stages of this research.

\section{References}

[1] NAAMAN, A. E. Prestressed Concrete. Analysis and Design: Fundamentals. $2^{\circ}$ Edition, 2004.

[2] LEONHARDT, F., MONNIG, E. Concrete constructions, basic principles on reinforcement concrete reinforcements. São Paulo - SP. Interciência Ltda., Vol. 3, 1977, 2007.

[3] $\mathrm{ACl}$ 318. Building Code Requirements for Structural Concrete, American Concrete Institute, Farmington Hills, Michigan, 2011.

[4] Eurocode 2, Design of Concrete Structures-Part 1-1: General Rules and Rules for Buildings, CEN, EN 1992-1-1, Brussels, Belgium, 2004.

[5] BRASILIAN ASSOCIATION OF TECHNICAL STANDARDS. NBR 6118 - Design of reinforced concrete structures. Rio de Janeiro, 2014.

[6] LASKAR. A, HSU T.T.C, MO. Y. L. Shear Strengths of Prestressed Concrete Beams Part 1: Experiments and Shear Design Equations. ACI Structural Journal, May-June, 2010.

[7] MACGREGOR, J. G., Strength and Behavior of Prestressed Concrete Beams with Web Reinforcement. PhD thesis, University of Illinois, July, 1960.

[8] ACl-ASCE Committee 426 (1973). The Shear Strength of Reinforced Concrete Members. In: Journal of the Structural Division, Vol. 99, N ST6, June, 1973, pp. 1091-1187.

[9] BRASILIAN ASSOCIATION OF TECHNICAL STANDARDS. NBR 5738 - Molding and cure of concrete proofs. Rio de Janeiro, 1994.

[10] BRASILIAN ASSOCIATION OF TECHNICAL STANDARDS. NBR 7222 - Concrete and mortar - Tensile strength determination through diametric compression of cylindrical concrete proofs. Rio de Janeiro, 1994.

[11] BRASILIAN ASSOCIATION OF TECHNICAL STANDARDS. NBR 8522 - Concrete - Determination of the elastic modulus and stress-strain curve. Rio de Janeiro, 2003.

[12] BRASILIAN ASSOCIATION OF TECHNICAL STANDARDS, NBR 7480 - Steel bars for reinforced concrete. Rio de Janeiro, 1996. 